Environment Conservation Journal 20 (1\&2) 75-79, 2019

ISSN 0972-3099 (Print) 2278-5124 (Online)

Abstracted and Indexed

\title{
Optimization of harvesting stages for higher yield of Ocimum spp. in North Indian Plains
}

\author{
Gupta M. 四
}

Received: 25.12.2018

Revised: 28.02 .2019

Accepted: 25.05.2019

\begin{abstract}
Sweet basil (Ocimum basilicum L.) is a popular culinary herb belongs to the family Lamiaceae. Basil also named as great basil or saint-joseph-wart. Leaf of basil has a pungent \& strong taste some Asian basils have a clove like flavour. Basil used as a culinary herbs have been reported to posses antioxidant activities. A field experiment was conducted at the research farm of CSIR-Central Institute of Medicinal and Aromatic Plant,Research Centre, Pantnagar (U.S.Nagar) Uttarakhand.India during kharif season 2018. The highest oil yield observed in $T_{2}$ Cim-Snigdha (126.99 kg/ha) as compared to $T_{3}$ Cim-Soumya $(108.64 \mathrm{~kg} / \mathrm{ha}), T_{5} \mathrm{Cim}-$ Surabhi $(86.22 \mathrm{~kg} / \mathrm{ha})$ as compared to others. The lowest oil yield $(37.90 \mathrm{~kg} / \mathrm{ha})$ recorded in $\mathrm{T}_{4}$ Cim-Jyoti. Oil yield also differ at different harvest stages of different Ocimum $\mathrm{sp}$. The highest oil yield $142.69 \mathrm{~kg} / \mathrm{ha}$ observed at $100 \%$ flowering stage $\left(S_{4}\right)$ as compared to $138.56 \mathrm{~kg} / \mathrm{h}$ at seed setting stage $\left(S_{5}\right), 63.60$ $\mathrm{kg} / \mathrm{ha}$ at $50 \%$ flowering stage $\left(S_{3}\right)$, and $56.63 \mathrm{~kg} / \mathrm{ha}$ at bud initiation stage $\left(\mathrm{S}_{2}\right)$. The lowest oil yield $25.54 \mathrm{~kg} / \mathrm{ha} \mathrm{recorded}$ at pre budding stage $\left(S_{1}\right)$. The highest oil yield $267.00 \mathrm{~kg} / \mathrm{ha}$ was recorded in $T_{3} S_{4}$ interaction of variety and harvest stages (Cim-Soumya at $100 \%$ flowering) as compared to other treatments. Therefore recommended the Ocimum should be harvest at $100 \%$ flowering stage to get maximum oil yield and return to the farmers as compared to other.
\end{abstract}

Key words: Ocimum basilicum L., bud initiation stage, perennial, mediterranian basils

\section{Introduction}

Sweet basil (Ocimum basilicum L.) is a popular culinary herb belongs to the family Lamiaceae. Basil also named as great basil or saint-joseph-wart. The original place of basil is central Africa to Southeast Asia. It is a tender plant \& used in cuisines worldwide. Traditionally basil is a green plant, some varieties, such as leaves purple in color. Basil grows between $30-130 \mathrm{~cm}$ (12-51in) is tall, with opposite, light green, silky leaves $3-11 \mathrm{~cm}$ (1.2-4.3in) long and 1-6cm (1.2-4.3in) long and 1$6 \mathrm{~cm}(0.39-2.36 \mathrm{in})$ in broad. The flowers are small, white in color and arranged in a terminal spike. Basil leaves have wilted from lack of water. Yellow leaf of bottom indicated plant stressed. Basil can also be propagated reliably from cuttings with the stem short cutting soak in water until roots develop. It can be cultivated as annual/ seasonal to perennial depends on climatic conditions as in frost prone area as seasonal and in hot area as perennial. Basil has shown antioxidant and antimicrobial activities due to its phenolic and aromatic compounds

Author's Address

117/622, Q Block, Sharda Nagar, Kanpur 208025 (U.P.)

E-mail.: gupta_monika2005@yahoo.com
(Gutierrez et al., 2008; Hussain et al., 2008; Suppakul et al., 2003). Leaf of basil has a pungent and strong taste some Asian basils have a clove like flavor. Its stronger then the mediterranian basils. Basil is commonly used in fresh because cooking quickly destroy the flavor.it is a main ingredients in pesto dish. Basil used as a Culinary herbs have been reported to posses antioxidant activities (Yanishlieva et al., 2006) suggesting that they might have potential human health benefits. The aromatic and curative properties of basil are connected with the presence of essential oil, mainly in the leaves and flowers. Basil essential oil is used to flavours foods, dental and oral products in fragrances and in medicines. Basilicum sp. Contains high concentration of Linalool \& Methyl chevicol 3:1 ratio aroma basil have 1,8-cineale \& methyl eugenol. Basilicum sp. Cim-Soumya, CimSharda, Cim-Surabhi and Cim-Jyoti released by CSIR-CIMAP. Cim-Soumya have a two strong component i.e. methyl chevicol (62.5-77.6\%) and linalool (14.4-34.1\%). Chemical component of Cim-sharda in methyl chevicol, 1,8cineole,linalool, l-campher, limonene, campene 
germacrene D. Methyl eugenol major compound of Cim-Sharda. Cim-Surabhi survive better in winter season comparison to other basilicum sp. CimSurabhi have higher linalool content (70-75\%) with low amount of linalool acetate $(8.50 \%)$. CimSurabhi also suitable for rainfed cultivation (March-December). Cim-Jyoti of Ocimum africanum essential oil compound is citrol, 1,8cineole, linalool, L-camphor ,limonene, eugenol, comphene germacrene-D. is the major compound. Major compound of Cim-Snigdha is methyl cinnamate is widely used in aroma, pharmaceutical $\&$ cosmetic industries. The new strains of Ocimum basillicum (OBH-3 now christened as CimSnigdha). Cim-Snigdha is an improved herb oil yield variety content $(78.7 \%)$ methyl cinnamate (CSIR-CIMAP, 2015). This variety regularly recorded a higher biomass \& oil yield. At present the demand of Ocimum oil is done on the basis of oil type and its increasing in day by day on national and international market at the same time gap between demand and supply also increased. Demand is very high comparison to production rate. At present market price of Ocimum oil is 1000-1200 per kg oil.

\section{Materials and Methods}

Experimental site: A field experiment was conducted at the research farm of CSIR-Central Institute of Medicinal and Aromatic Plant, Research Centre, Pantnagar (U.S.Nagar) Uttarakhand India during kharif season 2018. The experimental site is located between $29^{\circ} \mathrm{N}$ latitude and $70.38 \mathrm{E}$ longitudes and at an altitude of $243 \mathrm{~m}$ above mean sea level. The maximum temperature ranges between 35 to $45^{\circ} \mathrm{C}$, and minimum between $2^{\circ} \mathrm{C}$ to $5^{\circ} \mathrm{C}$. the experimental soil was sandy-loam in texture, neutral in reaction $(7.2 \mathrm{ph})$, medium in organic carbon ( $0.52 \%)$, low in available nitrogen ( $135 \mathrm{~kg} \mathrm{ha}^{-1}$ ), and medium in available phosphorus ( $13 \mathrm{~kg} \mathrm{ha}^{-1}$ ) as well as in potassium ( $140 \mathrm{~kg} \mathrm{ha}^{-}$The experimental design is randomized block design five treatment and five harvesting stages.

Transplanting material: The crop is propagated by seed. $500 \mathrm{gm}$ seed required in one hectare field for raising nursery.

Raising of nursery: The raised nursery of basil sp. (Cim-Surabhi, Cim-Jyoti, Cim-Soumya, CimSnigdha and Cim-Sharda) by seed. The seeds of
Ocimum were shown on 21/05/2018 in well pulverized field at $1-2 \mathrm{~cm}$ depth in row. The sizes of each bed with inter row spacing of $15 \mathrm{~cm}$ and intra row spacing is continuous. Seeds were covered by fine soil of the field and provided light irrigation just after covering. Nursery beds were irrigated as per the need of crop.

Field preparation: Recommended dose of fertilizers were applied @ 80:60:40 NPK/ha. The full dose of $\mathrm{P} \& \mathrm{~K}$ and $1 / 3^{\text {rd }}$ of $\mathrm{N}$ applied as basal and remaining $2 / 3^{\text {rd }}$ dose of $\mathrm{N}$ applied in two equal splits at $25 \& 40$ days after transplanting. Irrigate the crop as and when desired. The appropriate plant protection measures were followed. The crop was kept free from weeds by hand weeding.

\section{Experimental design and details of treatments}

The field experiment was laid out in a Factorial Randomized Block Design with five Ocimum spp. (Cim-Sharda, Cim-Snigdha, Cim-Somya, CimSurabhi) and Ocimum africanum (Cim-Jyoti) and five harvest stages i.e. $\mathrm{S}_{1}$-pre budding stage, $\mathrm{S}_{2^{-}}$ bud initiation stage, $\mathrm{S}_{3}-50 \%$ flowering, $\mathrm{S}_{4}-100 \%$ flowering (full blooming), $\mathrm{S}_{5}$-seed setting stage in three replications. The numerical data of all the components were subjected to analysis of variance (ANOVA) using randomized block design. Statistical analysis of data was done following standard procedures (Snedecor and Cochran, 1967).

Transplantation of crop: Transplanting of seedling is done in 15/06/2018 with treatment spacing row to row $40 \mathrm{~cm}$ and plant to plant $30 \mathrm{~cm}$. Transplanted to the respected field at 3-4 leaf stage (25 days old seedlings).

Growth and yield analysis: The effect of sweet basil Ocimum basilicum L. (Cim-Sharda, CimSnigdha, Cim-Somya, Cim-Surabhi) and Ocimum africanum (Cim-Jyoti) as $\mathrm{T}_{1}$ Cim-Sharda, $\mathrm{T}_{2}$ CimSnigdha, $\mathrm{T}_{3}$ Cim-Soumya, $\mathrm{T}_{4}$ Cim-Jyoti and $\mathrm{T}_{5}$ Cim-Surabhi and harvest stages like i.e. $S_{1}$-pre budding stage, $\mathrm{S}_{2}$ - bud initiation stage, $\mathrm{S}_{3}-50 \%$ flowering, $\mathrm{S}_{4}-100 \%$ flowering (full blooming), $\mathrm{S}_{5^{-}}$ seed setting stages on plant height, number of branches, fresh herb yield, and oil yield.

\section{Results and Discussion}

The field experiment was conducted at the research farm of CSIR-CIMAP Research Center Pantnagar during kharif season 2018 to evaluate the effect of Ocimum spp. and harvest stages on plant height, 
Optimization of harvesting stages for higher yield of Ocimum spp.

number of branches, fresh herb yield, and oil yield of sweet basil Ocimum basilicum L. (Cim-Sharda, Cim-Snigdha, Cim-Somya, Cim-Surabhi) and Ocimum africanum (Cim-Jyoti) at different harvest stages like i.e. $\mathrm{S}_{1}$-pre budding stage, $\mathrm{S}_{2^{-}}$bud initiation stage, $S_{3}-50 \%$ flowering, $S_{4}-100 \%$ flowering (full blooming), $\mathrm{S}_{5}$-seed setting stage. Spacing Ocimum spp. transplanted at 40 and $30 \mathrm{~cm}$ as inter row and intra row spacing respectively. Fetilizers were applied @ 80:60:40 NPK/ha. The full dose of $\mathrm{P}$ and $\mathrm{K}$ and $1 / 3^{\text {rd }}$ of $\mathrm{N}$ applied as basal and remaining $2 / 3^{\text {rd }}$ dose of $\mathrm{N}$ applied in two equal splits at 25 and 40 days after transplanting. Irrigate the crop as and when desired. The appropriate plant protection measures were followed.

Plant height: The detailed scrutiny of table-1 revealed that the maximum plant height $(101.5 \mathrm{~cm})$ was recorded in $\mathrm{T}_{5}$ Cim-Surabhi followed by $(94.3$ cm) $\mathrm{T}_{3}$ Cim-Soumya, ( $93.9 \mathrm{~cm}$ ) $\mathrm{T}_{2}$ Cim-Snigdha, $(92.6 \mathrm{~cm}) \mathrm{T}_{1}$ Cim-Sharda, and the lowest plant height $(85.3 \mathrm{~cm})$ were recorded in $\mathrm{T}_{4}$ Cim-Jyoti.

The plant height at different growth stages of ocimum species also differ significantly the highest plant height $(134.3 \mathrm{~cm})$ recorded in $\mathrm{S}_{5}$ (seed setting stage) as compared to $(107.5 \mathrm{~cm})$ at $\mathrm{S}_{4}(100 \%$ flowering), $(88.7 \mathrm{~cm})$ at $\mathrm{S}_{3}(50 \%$ flowering $)$, $(69.3 \mathrm{~cm})$ at $S_{2}$ (bud initiation stage) the lowest plant height $(67.7 \mathrm{~cm})$ at $S_{1}$ (pre budding stage).

The interaction effect of Ocimum sp. and growth stage on plant height shows a highest plant height $(144.7 \mathrm{~cm})$ at $\mathrm{T}_{4} \mathrm{~S}_{5}$ Cim-Jyoti (seed setting stage) as followed by $(124.7 \mathrm{~cm})$ at $\mathrm{T}_{5} \mathrm{~S}_{4}$ Cim-Surabhi $(100 \%$ flowering), $(99.0 \mathrm{~cm})$ at $\mathrm{T}_{1} \mathrm{~S}_{3}$ Cim-Sharda $(50 \%$ flowering), $(86.0 \mathrm{~cm})$ at $\mathrm{T}_{5} \mathrm{~S}_{1}$ Cim-Surabhi ( pre budding stage) the lowest interaction $(83.0 \mathrm{~cm})$ recorded in Cim-Surabhi (bud initiation stage). The results obtained are in agreement with results obtained by (Ersahin, 2006)

Numbers of branches / plant: Table- 2 shows a detailed study of no. of branches of Ocimum $s p$. The maximum no. of branches (25) per plant was recorded in $\mathrm{T}_{1}$ Cim-Sharda and $\mathrm{T}_{5}$ Cim-Surabhi as compared to (23) per plant at $\mathrm{T}_{3}$ Cim-Soumya and $\mathrm{T}_{4}$ Cim-Jyoti. While lowest no. of branches (21) per plant was observed in $\mathrm{T}_{2} \mathrm{Cim}-\mathrm{Snigdha}$. The no. of branches differs at different growth stages of the experiment. The maximum no. of branches (29) per plant found in $\mathrm{S}_{3}$ (50\% flowering), as compared to (27) per plant at $S_{2}$ (bud initiation stage), (26) per plant at $S_{5}$ (seed setting stage) and (20) per plant at
$\mathrm{S}_{4}$ (100\% flowering stage). The lowest (15) per plant no of branches were recorded in $S_{1}$ (pre budding stage). The interaction $\mathrm{b} / \mathrm{w}$ harvest stage and different sp. The heighest (36) per plant no. of branches observed at $\mathrm{T}_{5} \mathrm{~S}_{5}$ Cim-Surabhi (seed setting stage) as followed (35) per plant $\mathrm{T}_{1} \mathrm{~S}_{3} \mathrm{Cim}-$ Sharda (50\% flowering stage), (28) per plant CimSoumya (bud initation stage), (22) per plant CimSnigdha ( $100 \%$ flowering stage). The lowest (20) interaction of no.of branches were recorded in $\mathrm{T}_{1} \mathrm{~S}_{1}$ Cim-Sharda (pre budding stage). The similar trends of results were reported by Ekren et al., 2009.

Fresh herb yield: The detailed fresh herb yield of Ocimum $s p$ experiment describe in table-3.the highest fresh herb yield (144.67 q/ha) observed at $\mathrm{T}_{1}$ Cim-Sharda as compared to (139.57 q/ha) $\mathrm{T}_{2}$ Cim-Snigdha, (126.2 q/ha) $\mathrm{T}_{5}$ at Cim-Surabhi, (107.19 q/ha) $\mathrm{T}_{3}$ at Cim-Soumya. The lowest fresh herb yield (93.95q/ha) found in T4 Cim-Jyoti. Fresh herb yield of Ocimum spp. also differ significantly at different harvest stages. The highest fresh herb yield $(217.104 \mathrm{q} / \mathrm{ha}) \mathrm{S}_{5}$ seed setting stage as compared to $(145.68 \mathrm{q} / \mathrm{ha})$ at $\mathrm{S}_{4} 100 \%$ flowering, (118.61q/ha) at $S_{3} 50 \%$ flowering, $(67.55 \mathrm{q} / \mathrm{ha})$ at $S_{1}$ pre budding stage. The lowest fresh herb yield (62.70q/ha) observed in $S_{2}$ bud initiation stage. Fresh herb yield of Ocimum spp. interaction between varieties and harvest stage. The highest fresh herb yield (330.96 q/ha) were recorded in $\mathrm{T}_{1} \mathrm{~S}_{5}$ Cim-Sharda at seed setting stage as comparesd to $(196.44 \mathrm{q} / \mathrm{ha}) \quad \mathrm{T}_{5} \mathrm{~S}_{4}$ Cim-Surabhi at $100 \%$ flowering, (178.32 q/ha) Cim-Sharda at $50 \%$ flowering, (108.80 q/ha) Cim-Surabhi at bud initiation stage. Lowest fresh herb yield recorded in (51.20 q/ha) Cim-Jyoti at pre budding stage. The similar observations were reported by Ekren et al., 2009; Ersahin, 2006; Nurzynska-Wierdak, 2007.

Oil yield: Table- 4 shows an effect of oil yield of Ocimum spp. in different varieties \& harvest stages. The highest oil yield observed in $(126.99 \mathrm{~kg} / \mathrm{ha})$ at $\mathrm{T}_{2} \mathrm{Cim}-S n i g d h a$ as compared to $(108.64 \mathrm{~kg} / \mathrm{ha})$ at $\mathrm{T}_{3}$ Cim-Soumya, $(86.22 \mathrm{~kg} / \mathrm{ha})$ at $\mathrm{T}_{5}$ Cim-Surabhi and $(67.26 \mathrm{~kg} / \mathrm{ha})$ at $\mathrm{T}_{1} \mathrm{Cim}-\mathrm{Sharda}$. The lowest oil yield $(37.90 \mathrm{~kg} / \mathrm{ha})$ recorded in $\mathrm{T}_{4}$ Cim-Jyoti. Oil yield also differ at different harvest stages of different Ocimum spp. The highest oil yield (142.69 $\mathrm{kg} / \mathrm{ha}$ ) at $\mathrm{S}_{4} 100 \%$ flowering stage as compared to $(138.56 \mathrm{~kg} / \mathrm{ha})$ at $S_{5}$ seed setting stage, $(63.60 \mathrm{~kg} / \mathrm{ha})$ at $\mathrm{S}_{3} 50 \%$ flowering stage, $(56.63 \mathrm{~kg} / \mathrm{ha})$ at $\mathrm{S}_{2}$ bud initiation stage. The lowest oil yield $(25.54 \mathrm{~kg} / \mathrm{ha})$ 


\section{Gupta}

Table 1. Effect of different varieties and harvest stages on plant height of Ocimum spp.

\begin{tabular}{|l|l|l|l|l|l|l|}
\hline Treatment & $\mathrm{S}_{1}$ & $\mathrm{~S}_{2}$ & $\mathrm{~S}_{3}$ & $\mathrm{~S}_{4}$ & $\mathrm{~S}_{5}$ & Mean \\
\hline $\mathrm{T}_{1}$ & 63.0 & 67.3 & 99.0 & 92.0 & 141.7 & 92.6 \\
\hline $\mathrm{T}_{2}$ & 70.0 & 74.3 & 94.7 & 110 & 120.3 & 93.9 \\
\hline $\mathrm{T}_{3}$ & 71.3 & 67.3 & 86.3 & 104.7 & 141.7 & 94.3 \\
\hline $\mathrm{T}_{4}$ & 48.3 & 54.3 & 73.0 & 106.3 & 144.7 & 85.3 \\
\hline $\mathrm{T}_{5}$ & 86.0 & 83.0 & 90.7 & 124.7 & 123.3 & 101.5 \\
\hline Mean & 67.7 & 69.3 & 88.7 & 107.5 & 134.3 & \\
\hline SoV & $\mathrm{S}$ & $\mathrm{T}$ & & $\mathrm{S}$ ( & \\
\hline $\mathrm{SEm}_{ \pm}$ & 0.58 & 0.58 & & 2.90 \\
\hline LSD $_{(\mathrm{P}=0.05)}$ & 1.64 & 1.64 & & 8.24 \\
\hline
\end{tabular}

Table 2. Effect of different varieties and harvest stages on number of branches of Ocimum spp.

\begin{tabular}{|l|l|l|l|l|l|l|}
\hline Treatment & $\mathrm{S}_{1}$ & $\mathrm{~S}_{2}$ & $\mathrm{~S}_{3}$ & $\mathrm{~S}_{4}$ & $\mathrm{~S}_{5}$ & Mean \\
\hline $\mathrm{T}_{1}$ & 20 & 26 & 35 & 19 & 24 & 25 \\
\hline $\mathrm{T}_{2}$ & 12 & 27 & 29 & 22 & 15 & 21 \\
\hline $\mathrm{T}_{3}$ & 14 & 28 & 24 & 21 & 28 & 23 \\
\hline $\mathrm{T}_{4}$ & 12 & 27 & 30 & 18 & 29 & 23 \\
\hline $\mathrm{T}_{5}$ & 17 & 28 & 27 & 19 & 36 & 25 \\
\hline Mean & 15.0 & 27 & 29 & 20 & 26 & \\
\hline SoV & $\mathrm{S}$ & $\mathrm{T}$ & & $\mathrm{S}$ & \\
\hline $\mathrm{SEm}_{ \pm}$ & 0.60 & 0.60 & & 3.04 \\
\hline LSD $_{(\mathrm{P}=0.05)}$ & 1.73 & 1.73 & & 8.65 \\
\hline
\end{tabular}

Table 3. Effect of different varieties and harvest stages on fresh weight q/ha of Ocimum spp.

\begin{tabular}{|l|l|l|l|l|l|l|}
\hline Treatment & $\mathrm{S}_{1}$ & $\mathrm{~S}_{2}$ & $\mathrm{~S}_{3}$ & $\mathrm{~S}_{4}$ & $\mathrm{~S}_{5}$ & Mean \\
\hline $\mathrm{T}_{1}$ & 75.60 & 38.88 & 178.32 & 99.60 & 330.96 & 144.67 \\
\hline $\mathrm{T}_{2}$ & 74.64 & 62.31 & 139.47 & 172.08 & 249.36 & 139.57 \\
\hline $\mathrm{T}_{3}$ & 65.64 & 55.24 & 59.15 & 183.84 & 172.08 & 107.19 \\
\hline $\mathrm{T}_{4}$ & 51.20 & 48.29 & 130.76 & 76.44 & 163.08 & 93.95 \\
\hline $\mathrm{T}_{5}$ & 70.68 & 108.80 & 85.35 & 196.44 & 170.04 & 126.26 \\
\hline Mean & 67.55 & 62.70 & 118.61 & 145.68 & 217.104 & \\
\hline SoV & $\mathrm{S}$ & $\mathrm{T}$ & & $\mathrm{S} * \mathrm{~T}$ & \\
\hline $\mathrm{SEm}_{ \pm}$ & 1.93 & 1.93 & & 9.66 \\
\hline LSD $_{(\mathrm{P}=0.05)}$ & 5.49 & 5.49 & & 27.46 \\
\hline
\end{tabular}

Table 4. Effect of different varieties and harvest stages on oil yield L/ha of Ocimum spp.

\begin{tabular}{|l|l|l|l|l|l|l|}
\hline Treatment & $\mathrm{S}_{1}$ & $\mathrm{~S}_{2}$ & $\mathrm{~S}_{3}$ & $\mathrm{~S}_{4}$ & $\mathrm{~S}_{5}$ & Mean \\
\hline $\mathrm{T}_{1}$ & 14.73 & 41.75 & 101.00 & 50.00 & 128.84 & 67.26 \\
\hline $\mathrm{T}_{2}$ & 43.62 & 86.00 & 88.12 & 167.19 & 250.00 & 126.99 \\
\hline $\mathrm{T}_{3}$ & 23.00 & 68.17 & 34.51 & 267.00 & 150.54 & 108.64 \\
\hline $\mathrm{T}_{4}$ & 22.32 & 23.68 & 51.32 & 44.62 & 47.58 & 37.90 \\
\hline $\mathrm{T}_{5}$ & 24.03 & 63.55 & 43.05 & 184.65 & 115.82 & 86.22 \\
\hline Mean & 25.54 & 56.63 & 63.60 & 142.69 & 138.56 & \\
\hline SoV & $\mathrm{S}$ & $\mathrm{T}$ & & $\mathrm{S}$ & \\
\hline SEm & & 1.18 & & 5.88 & \\
\hline LSD $_{(\mathrm{P}=0.05)}$ & 3.34 & 3.34 & & 16.72 \\
\hline
\end{tabular}

$\mathrm{T}_{1}$ Cim-Sharda, $\mathrm{T}_{2}$ Cim-Snigdha, $\mathrm{T}_{3}$ Cim-Soumya, $\mathrm{T}_{4}$ Cim-Jyoti and $\mathrm{T}_{5}$ Cim-Surabhi, $\mathrm{S}_{1}$-pre budding stage, $\mathrm{S}_{2}$ - bud initiation stage, $\mathrm{S}_{3}-50 \%$ flowering, $\mathrm{S}_{4}-100 \%$ flowering (full blooming), $\mathrm{S}_{5}$-seed setting stage 
Optimization of harvesting stages for higher yield of Ocimum spp.

recorded in $S_{1}$ pre budding stage. The interaction effect of Ocimum species and different harvest stages were also differ. The highest $(267.00 \mathrm{~kg} / \mathrm{ha})$ oil yield interaction shows in $\mathrm{T}_{3} \mathrm{~S}_{4}$ Cim-Soumya at $100 \%$ flowering as compared to $(250.00 \mathrm{~kg} / \mathrm{ha})$ $\mathrm{T}_{2} \mathrm{~S}_{5}$ at Cim-Snigdha seed setting stage, (101.00 $\mathrm{kg} / \mathrm{ha}) \mathrm{T}_{1} \mathrm{~S}_{3}$ Cim-Sharda 50\% flowering, (86.00 $\mathrm{kg} / \mathrm{ha}) \mathrm{T}_{2} \mathrm{~S}_{2}$ Cim-Snigdha bud initiation stage. The lowest interaction of oil yield recorded in (43.62 $\mathrm{kg} / \mathrm{ha}$ ) $\mathrm{T}_{2} \mathrm{~S}_{1}$ Cim-Snigdha at pre budding stage.

\section{Conclusion}

The observation recorded revealed that among Ocimum spp. Variety $\mathrm{T}_{2}$ Cim-Snigdha provided highest oil yield (126.99 q/ha). While harvesting of Ocimum spp. at $\mathrm{S}_{4}(100 \%$ flowering stage $)$ provided highest oil yield as compared to other stages. The interaction effect of variety \& harvest stages are also differ significantly maximum oil yield of Ocimum spp. $\mathrm{T}_{3}$ Cim-Soumya at $100 \%$ flowering stage provided highest oil yield (267.00 $\mathrm{q} / \mathrm{ha})$. Therefore recommended the Ocimum should be harvest at $100 \%$ flowering stage to get maximum oil yield and return to the farmers as compared to other.

\section{References}

Director, CSIR-CIMAP. 2015. Improved varieties of Medicinal and aromatic Plants: CSIR-CIMAP's contribution. CSIR-Central Institute of Medicinal \& aromatic Plants, Lucknow. 1-153.
Ekren, S., Sönmez, C., Sancaktaroğlu, S. and Bayram, E. 2009. Effects of different plant densities on yield and quality characteristics of Sweet Basil (Ocimum basilicum L.). Ege University, Journal of Agriculture Faculty, 46(3): 165-173.

Erşahin, L. 2006. Quality and agronomic properties of sweet basil (Ocimum basilicum 1.) grown in Diyarbakır ecological. Conditions. Department of Field Crops Institute of Natural and Applied Sciences University of Cukurova. Msc., 49 p.

Gutierrez, J. C. Barry-Ryan, and P. Bourke. 2008. The antimicrobial efficacy of plant essential oil combinations and interactions with food ingredients. Intl. J. Food Microbiol. 124: 91-97.

Hussain, A. I. F. Anwar, S. Sherazi, and Przybylski, R. 2008. Chemical composition, antioxidant and antimicrobial activities of basil (Ocimum basilicum) essential oils depends on season variations. Food Chem. 108: 986-995.

Nurzynska-Wierdak, R. 2007. Comparing the growth and flowering of selected basil (Ocimum basilicum L.) varieties. Acta Agrobotanica, 60(2): 127-131.

Snedecor, G. M. Cochran, W. G. 1967. Statistical Methods. Iowa State College Press, Amer., Iowa, USA.

Suppakul, P., Miltz, J., Sonneveld, K. and Bigger S. W. 2003. Antimicrobial properties of basil and its possible application in food packing. Journal of Agriculture and Food Chemistry, 51: 3197-3207.

Yanishlieva, N. V. E. Marinova, and Pokorny, J. 2006. Natural antioxidants from herbs and spices. Eur. $J$. Lipid Sci. Technol. 108: 776-793. 